\title{
Bioprocess Optimization for Enhanced Biogas Production from Grape Pulp Waste
}

\author{
C. Gopinathan ${ }^{1}$, A. T. Vivek ${ }^{2}$ \\ ${ }^{1,2}$ Bioprocess laboratory, Department of Biotechnology, University of Calicut, Tenjhipalam, P.O. -673635,Kerala, India
}

\begin{abstract}
India ranks as one of the largest producer of fruits and vegetables in the world. Grapes with an annual production of 2.48 million tonnes, is cultivated in an area of approximately 34,000 hectares in India, of which approximately 30-35\% is wasted due to improper cold storage facilities, transportation, lack of appropriate post harvest technologies and damage caused due to pests and diseases. In the grape processing industry, the major product is grape juice. Huge quantities of grape pomace (grape pulp) is accumulated which cause environmental pollution. Since grapes are rich in nutrients, these can be channelized through biomethanogenic pathway for the production of value added products like biomethane. The grape pulp contains more of carbon and less of nitrogen, supplementation of urea improves the biogas production. Similarly, the effect of various metal ions had a positive effect in enhancing the biogas production. The unique combination of metal ions was found to be stimulatory in boosting the production of biogas from this abundant raw material.
\end{abstract}

Keywords: Anaerobic digestion, Grape pulp waste, Biogas, Urea, and metal ions

\section{Introduction}

India is rich in terms of availability of agro-wastes including vegetable and fruit wastes. Since this can be used as sources of renewable energy, it leads to a cleaner environment in addition to generation of much needed bioenergy. The renewable technologies can play an important role in eradicating poverty in energy production and ensuring environmental sustainability. In India, approximately $8 \%$ of residential energy is procured from grid, while around $80 \%$ of the residential energy is generated by use of solid fuels and the remaining of the energy is liquid fuels. In order to meet the growing demand, imports on oil must be reduced and renewable based energy systems should be adopted emphasizing towards cleaner and environment friendly scenario [1].

Biogas is a remarkable alternative for generation of electricity and heat production compared to conventional fossil fuels [2]. It consists of 40 to $60 \%$ and 40 to $55 \%$ methane and carbon dioxide, respectively [3]. The trace elements have significant role in the performance and in the efficient functioning of anaerobic digesters [4]. Therefore, optimal supply of nutrients is essential as well the availability of free metal ion is a vital parameter should be taken into account [5-7].

Grapes (Vitis vinifera .L) are grown in both temperate and tropical climates. The grape berries are mainly employed for large-scale cultivation for wine processing industries and are also consumed as fruits, juice and as raisins. It is rich in sugars, vitamins, enzymes, mineral salts and phytochemicals that accounts for the major sensory characteristics of wines [8-10]. Ample research has substantiated that agro-industrial wastes can be used for biogas production in an economic way. Therefore, the use of grape wastes, as a raw material is needful for the development of efficient and environmental friendly technologies [11].
Hence, the purpose of this study was to investigate the utilization grape pulp waste as a raw substrate in biomethanation and to optimize of nitrogen and metal ion concentration needed in anaerobic digestion for enhancing the methane rich biogas production. Quantification of methane content of the total biogas produced was also part of this study.

\section{Materials and Methods}

The rotten grape/waste grapes were obtained from Palayam market, Kozhikode, Kerala, India. These were placed in polyethylene bags and kept under refrigerated conditions in the laboratory. The rotten pulp waste was processed for digestion in an anaerobic digester of total volume of $750 \mathrm{~mL}$ [12-14]. Fresh cow dung was used as the inoculum and the daily-displaced water was accurately measured using measuring cylinder that is equivalent to the amount of biogas produced for the respective experimental set-up.

\subsection{Biomethanation of grape pulp waste}

The experiment was done to determine the biogas production with raw grape pulp waste as substrate and was set-up as given in Table1.

Table 1: Composition of fermentation mixture for biomethanation of mango pulp waste

\begin{tabular}{|c|c|}
\hline Experimental set-up & Fermentation mixture \\
\hline Control & $17.5 \mathrm{~g}$ cow dung $+682.5 \mathrm{~mL}$ water \\
\hline Raw grape pulp & $\begin{array}{c}17.5 \mathrm{~g} \text { cow dung }+332.5 \mathrm{~mL} \text { grape pulp } \\
+350 \mathrm{~mL} \text { water }\end{array}$ \\
\hline
\end{tabular}

\subsection{Biomethanation of $\mathrm{pH}$ adjusted grape pulp waste}

$1 \mathrm{~N} \mathrm{NaOH}$ was used to adjust the $\mathrm{pH}$ of reaction mixture containing grape pulp waste and the experiment was setup as given in Table. 2 


\section{International Journal of Science and Research (IJSR) \\ ISSN (Online): 2319-7064}

Index Copernicus Value (2013): 6.14 | Impact Factor (2014): 5.611

Table 2: Composition of fermentation mixture for biomethanation of $\mathrm{pH}$ adjusted grape pulp waste

\begin{tabular}{|c|c|}
\hline Experimental set-up & Fermentation mixture \\
\hline Control & $17.5 \mathrm{~g}$ cow dung $+682.5 \mathrm{~mL}$ water \\
\hline $\begin{array}{c}\text { pH adjusted raw grape } \\
\text { pulp }\end{array}$ & $\begin{array}{c}17.5 \mathrm{~g} \text { cow dung }+332.5 \mathrm{~mL} \text { grape } \\
\text { pulp }+350 \mathrm{~mL} \text { water }\end{array}$ \\
\hline
\end{tabular}

\subsection{Biomethanation of grape pulp waste under varying concentration of urea supplementation}

In order to find out optimum concentration for biogas production, five individual reactions were prepared with varying concentrations of urea as given Table.3.

Table 3: Composition of fermentation mixture for biomethanation of grape pulp under varying concentrations of urea

\begin{tabular}{|c|c|}
\hline Experimental set-up & Fermentation mixture \\
\hline Control & $17.5 \mathrm{~g}$ cow dung $+682.5 \mathrm{~mL}$ water \\
\hline $\begin{array}{c}\mathrm{pH} \text { adjusted raw } \\
\text { grape pulp }\end{array}$ & $\begin{array}{c}17.5 \mathrm{~g} \text { cow dung }+332.5 \mathrm{~mL} \text { grape pulp } \\
+350 \mathrm{~mL} \text { water }\end{array}$ \\
\hline $\begin{array}{c}1 \% \text { Urea added w/v } \\
17.5 \mathrm{~g} \text { cow dung }+332.5 \mathrm{~mL} \text { grape pulp } \\
+350 \mathrm{~mL} \text { water }\end{array}$ \\
\hline $2 \%$ Urea added w/v \\
$\begin{array}{c}17.5 \mathrm{~g} \text { cow dung }+332.5 \mathrm{~mL} \text { grape pulp } \\
+350 \mathrm{~mL} \text { water }\end{array}$ \\
\hline $3 \%$ Urea added w/v \\
$\begin{array}{c}17.5 \mathrm{~g} \text { cow dung }+332.5 \mathrm{~mL} \text { grape pulp } \\
+350 \mathrm{~mL} \text { water }\end{array}$ \\
\hline $5 \%$ Urea added w/v \\
$\begin{array}{c}17.5 \mathrm{~g} \text { cow dung }+332.5 \mathrm{~mL} \text { grape pulp } \\
+350 \mathrm{~mL} \text { water }\end{array}$ \\
\hline $10 \%$ Urea added w/v \\
$\begin{array}{c}17.5 \mathrm{~g} \text { cow dung }+332.5 \mathrm{~mL} \text { grape pulp } \\
+350 \mathrm{~mL} \text { water }\end{array}$ \\
\hline
\end{tabular}

2.4 Impact of metal ions on biomethanation of grape pulp waste

Four independent reaction mixtures were set to study the influence of metal ions on the reaction mixture as given in Table.4. In all of these cases, $5 \%$ Urea was mixed.

\begin{tabular}{|c|c|}
\hline Experimental set-up & Fermentation mixture \\
\hline Negative Control & $17.5 \mathrm{~g}$ cow dung $+682.5 \mathrm{~mL}$ water \\
\hline Positive Control & $\begin{array}{c}17.5 \mathrm{~g} \text { cow dung }+332.5 \mathrm{~mL} \text { grape pulp }+ \\
350 \mathrm{~mL} \text { water }\end{array}$ \\
\hline $\mathrm{FeCl}_{2}$ & $\begin{array}{c}17.5 \mathrm{~g} \text { cow dung }+332.5 \mathrm{~mL} \text { grape pulp }+ \\
350 \mathrm{~mL} \text { water }+17.5 \mathrm{mg} \mathrm{FeCl} \\
\end{array}$ \\
\hline $\mathrm{MgCl}_{2}(25 \mathrm{ppm})$
\end{tabular}

\subsection{Biomethanation of grape pulp waste under different combinations and concentrations of metal ions}

To optimize the right combination and the concentration of metal ions, reaction mixture was set-up as given in Table.5.

Table 5 Composition of fermentation mixture for biomethanation of grape pulp waste under different combinations and concentrations of metal ions

\begin{tabular}{|c|c|}
\hline Experimental set-up & Fermentation mixture \\
\hline (Negative Control) & $17.5 \mathrm{~g}$ cow dung $+682.5 \mathrm{~mL}$ water \\
\hline (Positive Control) & $\begin{array}{c}17.5 \mathrm{~g} \text { cow dung }+332.5 \mathrm{~mL} \text { grape pulp }+ \\
350 \mathrm{~mL} \text { water }\end{array}$ \\
\hline A & $\begin{array}{c}\text { 17.5g cow dung }+332.5 \mathrm{~mL} \text { grape pulp }+ \\
350 \mathrm{~mL} \text { water }+3 \% \text { Urea }(\mathrm{w} / \mathrm{v})+25 \mathrm{ppm} \\
\mathrm{FeCl}_{2}+25 \mathrm{ppm} \mathrm{CaCl}_{2}+25 \mathrm{ppm} \mathrm{MgCl}_{2}+ \\
25 \mathrm{ppm} \mathrm{ZnCl}_{2}\end{array}$ \\
\hline B & $\begin{array}{c}\text { 17.5g cow dung }+332.5 \mathrm{~mL} \text { grape pulp }+ \\
350 \mathrm{~mL} \text { water }+3 \% \text { Urea }(\mathrm{w} / \mathrm{v})+25 \mathrm{ppm} \\
\mathrm{FeCl}_{2}+12.5 \mathrm{ppm} \mathrm{CaCl}_{2}+25 \mathrm{ppm} \mathrm{MgCl}_{2}+ \\
12.5 \mathrm{ppm} \mathrm{ZnCl}_{2}\end{array}$ \\
\hline $\mathrm{C}$ & $\begin{array}{c}\text { 17.5g cow dung }+332.5 \mathrm{~mL} \text { grape pulp }+ \\
350 \mathrm{~mL} \text { water }+3 \% \text { Urea }(\mathrm{w} / \mathrm{v})+25 \mathrm{ppm} \\
\mathrm{FeCl}_{2}+25 \mathrm{ppm} \mathrm{MgCl}_{2}\end{array}$ \\
\hline $\mathrm{D}$ & $\begin{array}{l}17.5 \mathrm{~g} \text { cow dung }+332.5 \mathrm{~mL} \text { grape pulp }+ \\
350 \mathrm{~mL} \text { water }+3 \% \text { Urea }(\mathrm{w} / \mathrm{v})+25 \mathrm{ppm} \\
\mathrm{FeCl}_{2}+25 \mathrm{ppm} \mathrm{CaCl}_{2}+25 \mathrm{ppm} \mathrm{MgCl}_{2}\end{array}$ \\
\hline
\end{tabular}

2.6 Biomethanation of grape pulp waste under optimized conditions and quantification of methane

The amount of $\mathrm{CH} 4$ contained in the biogas was quantified with $5 \% \mathrm{NaOH}$ scrubbing method. Positive control and negative control was set-up as give in Table.6.

Table 6: Composition of fermentation mixture for optimized biomethanation of grape pulp waste

\begin{tabular}{|c|c|}
\hline Experimental set-up & Fermentation mixture \\
\hline (Negative Control) & $17.5 \mathrm{~g}$ cow dung $+682.5 \mathrm{~mL}$ water \\
\hline (Positive Control) & $\begin{array}{c}17.5 \mathrm{~g} \text { cow dung }+332.5 \mathrm{~mL} \text { grape pulp }+ \\
350 \mathrm{~mL} \text { water }+3 \% \text { Urea }\end{array}$ \\
\hline Test & $\begin{array}{c}17.5 \mathrm{~g} \text { cow dung }+332.5 \mathrm{~mL} \text { grape pulp }+ \\
350 \mathrm{~mL} \text { water }+3 \% \text { Urea }+25 \mathrm{ppm} \mathrm{FeCl} 3+ \\
25 \mathrm{ppm} \mathrm{CaCl} 2+25 \mathrm{ppm} \mathrm{MgCl} 2\end{array}$ \\
\hline
\end{tabular}

\section{Results and Discussion}

The Fig. 1 and Table show the data regarding biomethanation of raw grape pulp wastes in comparison to control (Fresh cow dung and water) in a period of 10 days. The use of raw grape pulp waste gave $4.26 \mathrm{~L}$ of biogas, which is higher than control due to the presence of various sugars. In grapes, large portion of soluble sugars is present. Glucose and fructose are the main sugars in the juice and the sugar content of grapes varies between 150 to $250 \mathrm{~g} / \mathrm{L}$. In the unripe berries, glucose is the predominant sugar and the ripening stage, equal amounts of glucose and fructose is found. The concentration of fructose exceeds than that of glucose in overripe grapes. The variation in concentration glucose to fructose ratio depends upon among grape varieties. Fructose, glucose and sucrose differ significantly in sweetness. The order sweetness is: fructose is sweeter than sucrose, which is sweeter than glucose. In other words, on sweetness scale, if fructose is considered to be 100 , then sucrose is 84 and glucose is 66.India being agricultural country produces annually one million tonnes of agricultural waste, out of which 20-30\% wastage is due to improper handling, microbial spoilage, damage due to transportation and due to lack of appropriate storage facilities. In addition, fruit processing industries produce bulk amount of fruit wastes, which can be fermented to biogas and organic fertilizer. Living standards of a country is decided by energy consumption. Hence, implication of this 


\section{International Journal of Science and Research (IJSR) \\ ISSN (Online): 2319-7064 \\ Index Copernicus Value (2013): 6.14 | Impact Factor (2014): 5.611}

technology will reduce dependence on crude oil imports and fertilizer in order to satisfy its huge demand in the energy and environmental sector. Fig 2 and Table. 2 gives the production of biogas from $\mathrm{pH}$ adjusted grape pulp. It was found that cumulative biogas production was $10.382 \mathrm{~L}$ as compared to positive control (4.26 L). From Fig.3 and Table.3, it is proven the $5 \%$ Urea concentration is optimum for biogas production using raw grape pulp. Since grape is carbon rich substrate, the supplementation of nitrogen becomes necessary to optimize the required $\mathrm{C}: \mathrm{N}$ ratio $(25: 1$ to $30: 1)$.

Fig. 4 and Table. 4 represent the biomethanation of grape pulp with varying concentrations of metal ions. Various metal ions have got very important stimulatory role in the methanogenic pathway. Trace elements for anaerobic digestion include Iron, Magnesium, Calcium, Zinc, Copper and Cobalt, as these nutrients are essential for microbial metabolism. Acetate is the major precursor for methane production in an anaerobic digester and its utilization is a rate-limiting step. Rapid conversion of acetic acid to methane by addition of iron and magnesium in anaerobic digestion has been observed and $40 \%$ increase of biogas was reported previously. An essential nutrient can become toxic to microorganism if its concentration in the substrate increases. Inorganic cations such as $\mathrm{Ca}^{2+}, \mathrm{Mg}^{2+}, \mathrm{Fe}^{2+}$ and $\mathrm{Zn}^{2+}$ have stimulatory at normal concentrations whereas some heavy metals are toxic even at low concentrations. Such toxic heavy metal kills the microbe by inactivating the sulfhydryl group of their enzymes by forming mercaptides. Addition of $\mathrm{Fe}^{2+}$ resulted in a rapid increase in biogas production and methane content. Addition of $\mathrm{Mg}$ and $\mathrm{Ca}$ ions also increases the biogas production whereas Zinc ions decrease the production. The toxicity of heavy metals depends mainly on its concentration and other factors such as $\mathrm{pH}$. Also, the type of salt may affect heavy metal toxicity and it can be attributed principally to the multiplicity of complex or clusters they can form primarily at the plasma membrane Plasma permeabilization by heavy metals has been reported for a variety of microorganisms. Sulfide has been used to control heavy metal toxicity. However at high concentrations of sulfide can also inhibit methanogenesis or even precipitate essential trace elements.

It has been found that $\mathrm{FeCl}_{2}$ gives the maximum biogas production at $25 \mathrm{ppm}$ concentration mixed with grape pulp which is $6.62 \mathrm{~L}$ more biogas than the fermentation mixture devoid of metal ions. It is evident from Fig. 5 and Table. 5 that biogas production improved when the mixture contains $25 \mathrm{ppm}$ of $\mathrm{FeCl}_{2}, \mathrm{CaCl}_{2}$ and $\mathrm{MgCl}_{2}$ along with $5 \%$ Urea. The biogas production was $15.5 \mathrm{~L}$ more compared to control. As per fig. 6 and Table.6, $11.7 \mathrm{~L}$ of methane was produced under optimized conditions, which is equivalent to $59 \%$ methane content of the total biogas produced.

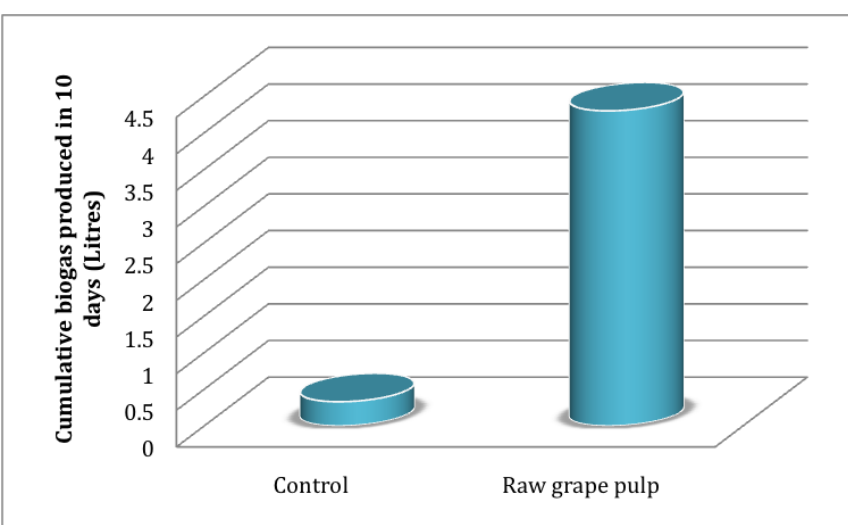

Figure 1: Biomethanation of grape pulp waste

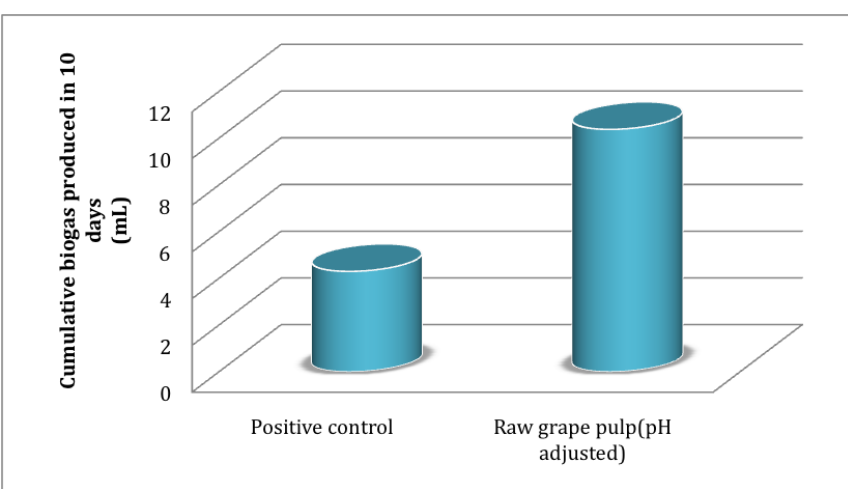

Figure 2: Biomethanation of $\mathrm{pH}$ adjusted grape pulp waste

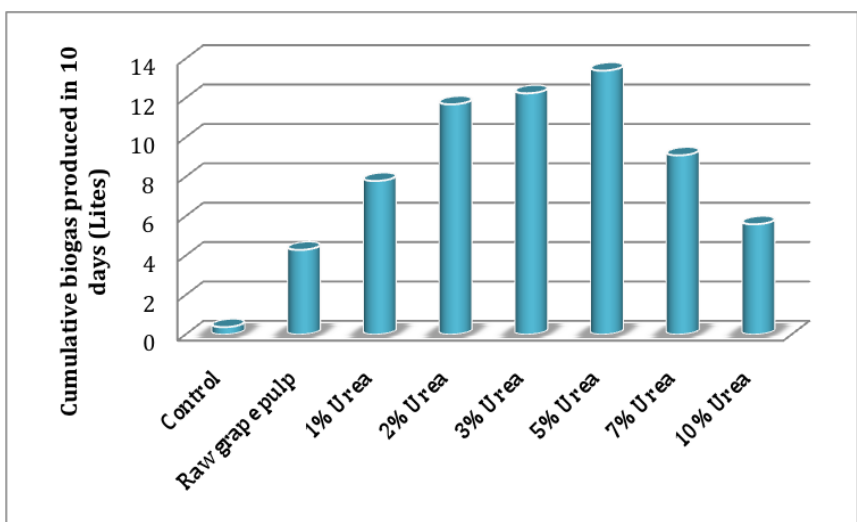

Figure 3: Biomethanation of grape pulp waste under varying concentration of urea supplementation

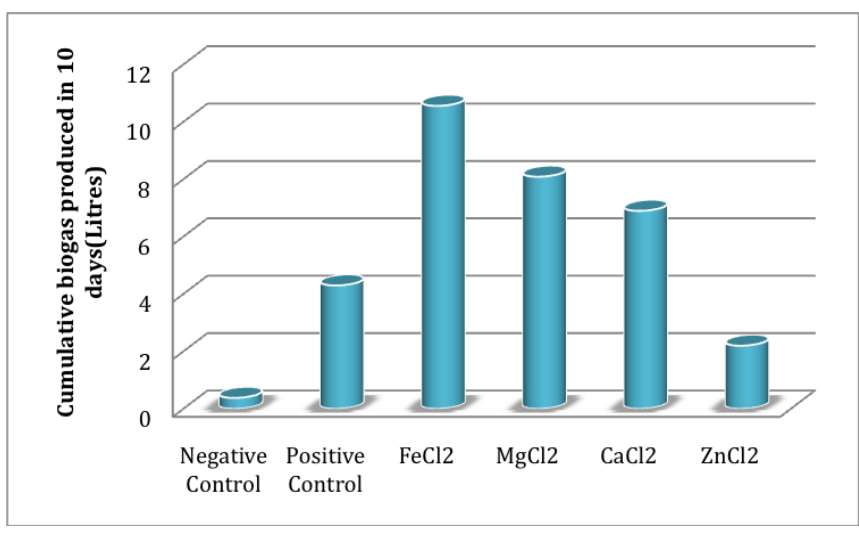

Figure 4: Impact of metal ions on biomethanation of grape pulp waste 


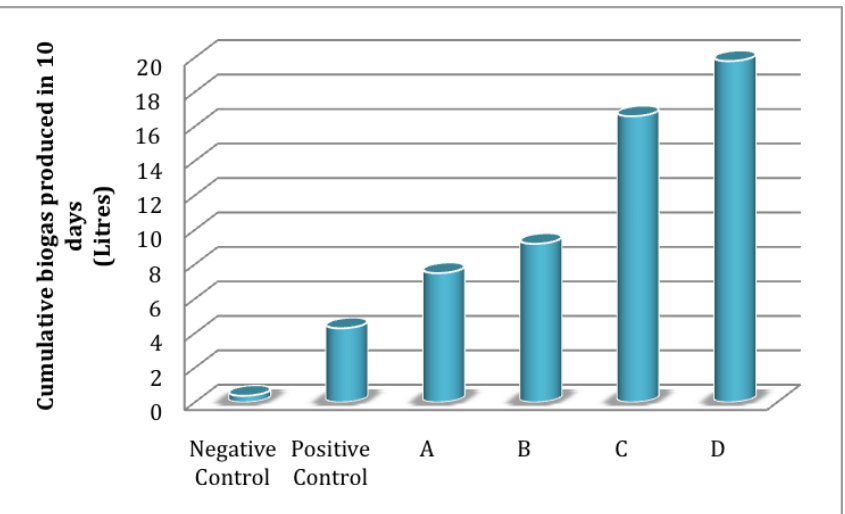

Figure 5: Biomethanation of grape pulp waste under different combinations and concentrations of metal ions

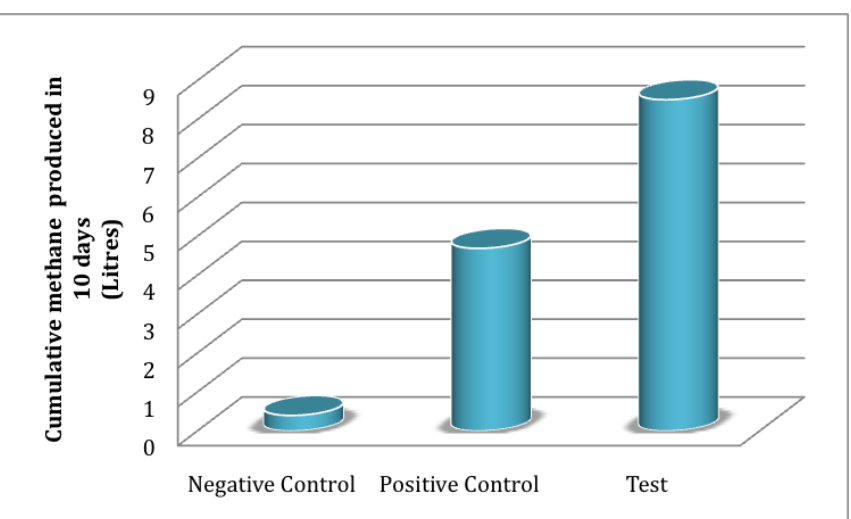

Figure 6: Biomethanation of grape pulp waste under different combinations and concentrations of metal ions

\section{Conclusion}

The present work provides the basic technical data required for scale-up of this cost-effective process using grape pulp waste as the raw material for biogas production. The profits can still improved by optimizing the media with urea and metal salts. The overall results show that grape pulp is an effective raw material for biogas production, making their utilization worthwhile and thus fostering progress towards sustainable development.

\section{References}

[1] Bhide, Anjali, and Carlos Rodríguez Monroy. "Energy poverty: a special focus on energy poverty in India and renewable energy technologies." Renewable and Sustainable Energy Reviews 15.2 (2011): 1057-1066

[2] Rasi, Saija, Jenni Lehtinen, and Jukka Rintala. "Determination of organic silicon compounds in biogas from wastewater treatments plants, landfills, and codigestion plants." Renewable Energy 35.12 (2010): 2666-2673.

[3] Schweigkofler, Martin, and Reinhard Niessner. "Determination of siloxanes and VOC in landfill gas and sewage gas by canister sampling and GC-MS/AES analysis." Environmental science \& technology 33.20 (1999): 3680-3685.

[4] Demirel, B., and P. Scherer. "Trace element requirements of agricultural biogas digesters during biological conversion of renewable biomass to methane." Biomass and Bioenergy 35.3 (2011): 992998.

[5] Bryant, M. P. "Microbial methane productiontheoretical aspects." Journal of Animal Science 48.1 (1979): 193-201.

[6] Callander, I. J., and J. P. Barford. "Precipitation, chelation, and the availability of metals as nutrients in anaerobic digestion. I. Methodology." Biotechnology and Bioengineering 25.8 (1983): 1947-1957.

[7] Callander, I. J., and J. P. Barford. "Precipitation, chelation, and the availability of metals as nutrients in anaerobic digestion. II. Applications." Biotechnology and Bioengineering 25.8 (1983): 1959-1972.

[8] Bunea, Claudiu-Ioan, et al. "Carotenoids, total polyphenols and antioxidant activity of grapes (Vitis vinifera) cultivated in organic and conventional systems." Chem Cent J 6.1 (2012): 66.

[9] Waterhouse, Andrew L. "Wine phenolics." Annals of the New York Academy of Sciences 957.1 (2002): 21-36.

[10] Walzem, R. L. "Wine and health: state of proofs and research needs." Inflammopharmacology 16.6 (2008): 265-271.

[11]Ferrer, J., et al. "Agronomic use of biotechnologically processed grape wastes." Bioresource Technology 76.1 (2001): 39-44.

[12] Aradhana Priyadarsini, A. T. Vivek, C. Gopinathan, "Cost Effective Production of Penicillin and Biogas from Rotten Oranges by Microbial Fermentation Technique", International Journal of Science and Research(IJSR),https://www.ijsr.net/archive/v5i4/v5i4.p hp, Volume 5 Issue 4, April 2016, 2379 - 2382

[13]C. Gopinathan, A. T. Vivek, "Process Optimization for Enhanced Biogas Production from Mango Pulp Waste", International Journal of Science and Research(IJSR),https://www.ijsr.net/archive/v5i5/v5i5_0 1.php, Volume 5 Issue 5, May 2016, 1772 . 1775,DOI:http://dx.doi.org/10.21275/v5i5.NOV163761

[14]C. Gopinatthan, Himanshu rohira, and Romilly margret Mendez, "Cost effective pretreatment of Cassava peels for enhanced Biogas production", IOSR Journal of Environmental Science, Toxicology and Food Technology (IOSR-JESTFT) e-ISSN: 2319-2402,pISSN: 2319-2399.Volume 9, Issue 9 Ver. II (Sep. 2015), PP 21-25

\section{Author Profile}

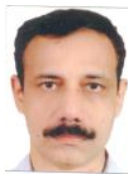

C.Gopinathan is currently working as Associate Professor at Department of Biotechnology, University of Calicut. He received the B.Sc in Botany, M.Sc in Life Sciences with specialization in Microbiology from University of Calicut and M.Tech in Biotechnology from Anna University, Chennai. He was former waste management consultant for Calicut Corporation, Kerala and is, at present consultant for Indian railways. He has handled various bioprocess scaled up projects and published \& presented his research works in leading Biotechnology conferences and International journals including World Biotechnology Congress. His specialization areas include fermentation technology in general and specifically biopesticide production, biogas production from agro waste, low cost mushroom production and high rate aerobic composting.

\section{Volume 5 Issue 3, March 2016 www.ijsr.net}

